\title{
Da ação à reação: o caso chinês na consolidação do monopólio de Elementos de Terras Raras à demanda na Organização Mundial do Comércio
}

From action to reaction: the Chinese case in the consolidation of the Rare Earth Elements monopoly and the complaint at the World Trade Organization

De la acción a la reacción: el caso chino en la consolidación del monopolio de elementos de tierras raras sobre la queja de la Organización Mundial de Comercio

1. Bacharelanda em Direito (UFPB), Mestre em Relações Internacionais (UEPB), João Pessoa/PB, Brasil.

2. Docente do Programa de Pós-Graduação em Relações Internacionais da Universidade Estadual da Paraíba (PPGRI/ UEPB) e do Programa de Pós-Graduação em Gestão Pública e Cooperação Internacional da Universidade Federal da Paraíba (PGPCI/UFPB), João Pessoa/ PB, Brasil. Orcid: orcid.org/0000-00020209-2717. (1D)

3. Docente do Programa de Pós-Graduação em Gestão Pública e Cooperação Internacional da Universidade Federa da Paraíba (PGPCI/UFPB), João Pessoa/ PB, Brasil. Orcid: orcid.org/0000-00020434-7656. (1D)
Mércia Cristina Gomes de Araújo'

Alexandre Cesar Cunha Leite ${ }^{2}$

Elia Elisa Cia Alves ${ }^{3}$

DOI: 10.5752/P.2317-773X.2020v8.n3.p152

Recebido em: 29 de novembro de 2019 Aceito em: 04 de março de 2020

\section{Resumo}

Qual a estratégia da China em mercados de recursos naturais em que tem grande participação na oferta? A partir de um estudo de caso eminentemente qualitativo, mas com ferramentais quantitativos, tais como índice de poder de monopólio do mercado de Elementos de Terras Raras (ETR), mostramos como a China consolidou-se como monopolista e como reagiu às acusações no sistema internacional de comércio. Os ETR não são terras e tampouco raras, mas caracterizam um importante insumo da cadeia produtiva comercial global, destacando-se, majoritariamente, nos sistemas de controle de mísseis, de defesa e de comunicação. Afinal, qual o interesse da China em obter o controle sobre a cadeia produtiva desse setor? Como o país alcançou isso e quais instrumentos de política industrial e comercial foram empregados? Qual a reação dos outros atores nesse mercado? Sugere-se que o objetivo de monopolizar a cadeia produtiva dos recursos naturais estratégicos de ETR foi em consolidar o poder econômico chinês. Mostramos como a China ocupou uma posição privilegiada no setor, galgando a posição de maior exportador destes elementos e forte poder de monopólio, calculado através de índices de elasticidade-preço da demanda e como foi seu posicionamento no litígio internacional.

Palavras Chave: China. Elementos de Terras Raras. Poder Econômico. Monopólio. 


\section{ABstract}

What is Chinese strategy in natural resource markets with a large supply participation? From an eminently qualitative case study, but with quantitative tools such as monopoly power index of the Rare Earth Elements (REE) market, we show how China has consolidated as a monopolist and how it has responded to the accusations in the international trading system. REEs are neither rare nor land, but they characterize an important input of the global trade supply chain, standing out mainly in missile control, defense and communication systems. After all, what is China's interest in gaining control over its production chain? How did the country achieve this and what instruments of industrial and trade policy were employed? What is the reaction of other actors in this market? It is suggested that the goal of monopolizing the supply chain of strategic RREs natural resources was to consolidate Chinese economic power. We show how China occupied a privileged position in the sector, reaching the position of largest exporter of these elements and strong monopoly power, calculated through price elasticity indices of demand and how it was positioned in the international dispute.

Keywords: China. Elements of Rare Earths. Economic Power. Monopoly.

\section{RESUMEN}

¿Cuál es la estrategia de China en los mercados de recursos naturales donde tiene una gran participación en el suministro? A partir de un estudio de caso eminentemente cualitativo, pero con herramientas cuantitativas como el índice de poder de monopolio de mercado de Elementos de tierras raras (ETR), mostramos cómo China se ha consolidado en la posición de monopolio y cómo ha respondido a las acusaciones en el sistema de comercio internacional Los ETR no son raros ni terrestres, pero caracterizan un aporte importante de la cadena de suministro del comercio mundial, destacando principalmente en los sistemas de control de misiles, defensa y comunicación. Después de todo, ¿cuál es el interés de China en obtener el control de su cadena de producción? ¿Cómo logró el país esto y qué instrumentos de política industrial y comercial se emplearon? ¿Cuál es la reacción de otros actores en este mercado? Se sugiere que el objetivo de monopolizar la cadena de suministro de los recursos naturales estratégicos ETR era consolidar el poder económico chino. Mostramos cómo China ocupó una posición privilegiada en el sector, alcanzando la posición de mayor exportador de estos elementos y un fuerte poder de monopolio, calculado a través de los índices de demanda de elasticidad de precios y cómo se posicionó en la disputa internacional.

Palabras clave: China. Elementos raros de la Tierra. Poder Económico. Monopolio.

Introdução

Desde a década de 1970, o campo teórico das Relações Internacionais (RI) tem cedido importante espaço à interdependência e complexidade dos problemas estatais. Ainda assim, em contraste com questões referentes aos jogos de poder entre os Estados, noções de soberania, instituições internacionais e relações comerciais, a disputa por recursos naturais não constitui o foco prioritário da área (FUSER, 2010). Grande parte da literatura apresenta recursos naturais estratégicos ${ }^{4}$ como fator condicionante à configuração do poder bélico (KLARE, 2000; KREMER, 2012), mesmo quando diante do mesmo objeto desse trabalho (MELO; HAMANA, 2015).
4. Um recurso natural estratégico é aquele que "é a chave do funcionamento do sistema capitalista de produção e/ ou para a manutenção da hegemonia regional e mundial" (RAMOS et al., 2010, p. 32). À medida que uma matéria-prima passa a ser potencialmente vital para 0 desenvolvimento de atividades econômicas, a sua escassez traz à tona um componente conflitivo da geopolítica em função da própria assimetria de sua dotação (SENHORAS, MOREIRA, VITTE, 2009). 
5. Terras raras (TR) ou Elementos de Terras Raras (ETR) compreendem uma série de elementos químicos que se encontram na tabela periódica entre o Lantânio (La;57) e o Lutécio (Lu;71). Somados a essa série estão os metais Escândio (Sc;21) e Ítrio (Y;39). Os ETR caracterizam-se como um importante insumo da cadeia produtiva comercial global, e destacam-se, majoritariamente, nos sistemas de controle de mísseis, de defesa e de comunicação (ROCIO; da SILVA; de CARVALHO; CARDOSO, 2013,

LEITE; ARAÚJO, 2015). Além disso, os

ETR são utilizados desde a composição de imãs, lasers, radares, lentes de câmeras, motores elétricos de automóveis até nas blindagens de reatores nucleares e em materiais usados no refino do petróleo.
Não obstante, esse trabalho busca desvencilhar-se de uma perspectiva militarizada dos recursos naturais. Do ponto de vista econômico, Oliveira (2010) salienta as alterações do sistema econômico mundial desde o pós $2^{\text {a }}$ Guerra Mundial, apontando a disputa pelo controle dos principais mercados do mundo, dentre os quais destacam-se as matérias-primas. Segundo esse autor, o crescimento econômico de países em desenvolvimento impulsionou a busca por uma maior projeção política de coparticipação nos processos decisórios internacionais. Nesse sentido, Ramos et al. (2018) destacam a maior articulação institucional da China, especialmente no que tange à busca por consolidar uma agenda de governança econômica paralela à dirigida pelos países desenvolvidos.

Leite (2011) destaca o dinamismo econômico chinês na esfera do comércio internacional, seja atuando como polo exportador, importador ou como investidor estrangeiro em grande escala. Alinhando seus interesses nos ambientes doméstico e internacional, no ano de 1978, sob orientação de Deng Xiaoping, a China seguiu rumo a uma economia voltada para o mercado (WALL, 1996; EGLIN, 1997). Consequentemente, a emergência chinesa alterou as estruturas produtivas globais. Particularmente, no setor primário, ao criar dinâmicas que impulsionaram uma grande demanda de recursos naturais, a China assumiu o posto de responsável pela alta dos preços internacionais de commodities, lugar que terminou por estabelecê-la como motor da expansão industrial extrativa em nível mundial (MORENO, 2015).

Diante disso, o artigo tem por objetivo analisar os recursos naturais estratégicos sob uma perspectiva da Economia Política Internacional (EPI), buscando compreender os Elementos de Terras Raras (ETR/TR ${ }^{5}$ empregados como um recurso de poder econômico pelo Estado chinês. Apesar do reducionismo das análises de EPI focarem nas relações entre Estado e Mercado, conforme aponta Gonçalves (2005), esse é um tema que perpassa toda a agenda dos estudos da área, seja por uma perspectiva mais liberal-institucional (FRIEDEN E LAKE, 2000) ou mais crítica. Diante desse quadro, busca-se compreender o interesse da China no controle sobre a cadeia produtiva dos ETR, sugerindo-se que, o controle das reservas, depósitos e do consumo de alto valor adicionado em produção de tecnologia high tech, confere à China maior poder de barganha, refletido no seu aumento de poder econômico. A China é o país ofertante desse recurso com maior importância no mercado, influenciando variáveis chave no funcionamento do mesmo, tais como preço e volume negociado.

Sobre esse tema Wubbeke (2013) bem como Kalantzakos (2018) destacam que os controles de exportação de ETR implementados pela China não podem ser analisados isoladamente e sugere que a explicação geopolítica, que vê os recursos naturais como instrumentos da política de poder, só pode ser parcialmente atribuída às políticas chinesas de ETR. Segundo o autor, é preciso considerar as demandas domésticas emergentes sobre a dimensão ambiental e de desenvolvimento industrial. Do ponto de vista metodológico, tal problemática será observada através do estudo do caso da estratégia de inserção monopolista chinesa nesse mercado, a partir da restrição da produção, com o ápice através da abertura de um painel na Organização Mundial do Comércio (OMC) em 2012 (OMC, 2015). 
A pertinência temática somada ao caráter atual do trabalho perpassa inúmeras questões. Primeiramente, conforme já mencionado, grande parte da produção acadêmica no Brasil sobre ETR é instrumentalizada pela análise militar-estratégica ou geopolítica (REIS, 2017). Em segundo lugar, há que se ressaltar que a escalada das disputas comerciais entre os EUA e a China, desde 2017, revela uma resposta à uma estratégia que vinha sendo construída pela potência emergente paulatinamente e consolidada desde o início dos anos 2000. Finalmente, ainda que não tenha a mesma ênfase que algumas commodities minerais mais conhecidas, as ETR têm amplo destaque nos meios relacionados às atividades mineradoras de pesquisa, exploração, produção, assim como de comercialização.

Para isso, o artigo está dividido em quatro partes, incluindo essa seção introdutória. Na seção 2, busca-se situar o debate do ponto de vista teórico e descrever como o país conseguiu se projetar no setor de ETR como grande monopolista, posição identificada a partir do cálculo de saliência das relações comerciais. Na seção 3, discute-se o caso de disputa na OMC, ilustrando como esse espaço foi instrumentalizado pelo país para consolidar sua estratégia. Finalmente, a seção 4 traz considerações finais.

0 mercado de Terras Raras e a ascensão chinesa nos anos 2000

Os ETR foram descobertos em território chinês no final da década de 1920, no distrito de Bayan Obo, cidade mineira localizada no oeste da Mongólia Interior. Até esta data (ou esta descoberta), sua produção era majoritariamente estadunidense. O interesse chinês em influir sobre os ETR era inexistente até meados da década de 1960. Esse cenário foi alterado no governo de Deng Xiaoping, particularmente a partir de 1986. Desde então, a China optou por uma estratégia de longo prazo, envolvendo desde o domínio da extração até a produção e rotas de distribuição (CARDOSO; PAZETTI; SANTOS, 2014).

Nos anos 1980, a China promoveu uma redução de preço para promover a desmobilização da extração dos insumos no resto do globo. Destarte, países como os EUA e o Japão optaram por não produzir e passaram a importar a matéria-prima da república asiática.

A estratégia chinesa pode ser analisada em três momentos distintos (LEITE; ARAÚJO, 2015):

(i) Aumento da demanda: ao formar grandes e atrativos estoques após a queda nos preços dos minerais no final da década de 1990; entre os anos 2000 e 2009. Nesse ponto, "a China tornou-se um mercado atrativo para importação de matérias de terras-raras" ${ }^{\prime \prime}$ (ROCIO; da SILVA; de CARVALHO; CARDOSO, 2013);

(ii) Restrição da oferta: após estabelecer planos de redução de quota de exportação em 2010, entre 2011 e 2013, a China aumentou a sua quota de produção de 89,20 toneladas métricas em 2010 para cerca de 93,80 toneladas métricas em 2011, um aumento de cerca de 5\%. Além disso, o Estado chinês impôs tarifas de exportação de $25 \%$ sobre determinados produtos, enquanto que os outros estariam sujeitos a uma tarifa de 15\% (LIMA, 2011. LEITE; ARAÚJO, 2015);
6. Com início em meados de 2003, a produção no país estruturou-se em dois grupos, o primeiro compreendendo as províncias de Mongólia Interior, de Gansu e de Sichuam, e com uma produção centrada em minérios detentores de bastnasita. 0 segundo grupo compreendendo as províncias de Guangdong, Human, Jiangxi e Jiangsu, com uma produção voltada para argilas enriquecidas com elementos pesados de TR (LEITE; ARAÚJO, 2015). 
(iii) Explosão do aumento dos preços dos insumos que, segundo Serra (2011), multiplicaram-se por 10.

Kay (2009) salienta que o poder econômico tem respaldo no poder de monopólio ou no monopsônio, ou seja, na existência de um único vendedor de um bem ou serviço particular ou na existência de um único comprador para esse bem. De acordo com Strange (1994), "é impossível ter poder político sem o poder de compra, para comandar a produção e mobilizar o capital. E é impossível ter poder econômico sem a sanção da autoridade política, sem a segurança jurídica e física. Isso só pode ser fornecido pela autoridade política" (STRANGE, 1994, p. 25).

Essa definição de poder econômico é particularmente importante. Isso porque, atentando-se para a definição de poder voltada para o controle sobre recursos naturais, existe uma crescente valoração histórica de sua geopolítica. Na medida em que a abundância de recursos em um território contrasta com a escassez em outro, dá-se início a uma natureza iminentemente conflitiva. Desse modo, no campo econômico, o poder de monopólio e o poder de produção distinguem os atores do sistema com mais ou menos poder frente aos demais.

Entretanto, segundo Nye (2012), a escassez de recursos em um determinado Estado não é indício de baixo poder econômico. Esse autor salienta que, sem uma parcela significativa de recursos naturais, no século XX o Japão alcançou o patamar de segunda maior economia do mundo. Por outro lado, países favorecidos de petróleo permaneceram fracos por não conseguirem transformar seu recurso em poder nacional ou riqueza. Destaca-se que concepção de poder como a capacidade de um ator usar seus recursos materiais convertendo-os e levando outros atores a fazerem o que eles não fariam em outra situação tem sido amplamente operacionalizada na política internacional.

A competição em torno do acesso às fontes de recursos valiosos acompanha a trajetória da humanidade desde a pré-história (KLARE, 2000; YERGIN, 2014). A esse respeito, Gilpin (1981) aponta que o efeito da lei dos retornos decrescentes, responsável pelo funcionamento econômico em qualquer sociedade e em qualquer período de tempo, impulsiona a disputa entre os atores pela posse de recursos valiosos. Observa-se, assim, que os recursos essenciais e difíceis de substituir, tornam-se sujeitos a certo grau de risco de seu fornecimento. Logo, entende-se que a geopolítica dos recursos naturais estratégicos está diretamente ligada a cinco fatores principais: "1. ao valor das commodities no mercado internacional, 2. às taxas de crescimento dos países que compõem o Sistema Internacional, 3. à escassez da mercadoria, 4. à sua utilidade e 5. à inelasticidade do bem" (MACHADO, 2012, p. 18).

Collier e Hoeffler (2004) "argumentam que a alta volatilidade dos preços internacionais de commodities faz com que os países importadores sejam confrontados com choques de preços internos" (LEITE; ARAÚJO, 2015), que impactam a economia doméstica dos Estados e requerem estratégias de gerenciamento adequadas, nem sempre aplicadas. A esse respeito, Peters (2004) argumenta que a perspectiva da emergência de conflitos relacionados com a escassez de recursos naturais somente despertou a atenção dos teóricos em 1973, a partir do primeiro choque do petróleo. 
Nota-se, portanto, que o controle de um recurso valioso pode se traduzir em poder. Segundo Strange (1994), o poder estrutural é composto por quatro subestruturas independentes e complementares. Nesse caso, salienta-se a importância da estrutura de produção para construção e/ou projeção de um poder econômico sólido. Essa estrutura de produção refere-se ao índice dos arranjos do Estado que determina os termos do que deve ser produzido, por quem e para quem. Logo, definir o que, como e para quem se produz é fundamental para o Estado que almeja deter poder na economia mundial.

Conforme o gráfico 1, as reservas de ETR encontram-se dispostas em diferentes regiões do globo, como nos Estados Unidos (EUA), na Europa, no Canadá, na Austrália e, principalmente, em solo chinês, com $39 \%$ das reservas globais.

Gráfico 1 - Disponibilidade de Reservas de Elementos de Terras Raras (Em milhões de toneladas)

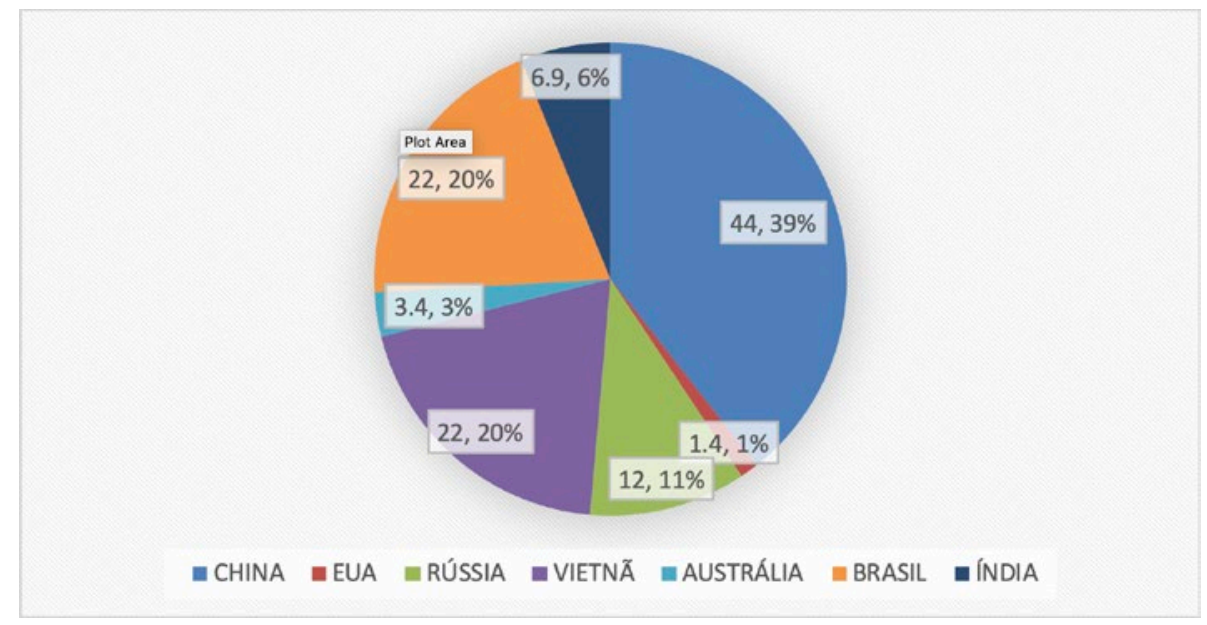

Fonte: Elaboração própria com base em USGS (2019). Atualizado de (LEITE; ARAÚJO, 2015).

Apesar de importante, um país pode possuir uma vasta reserva e optar por não explorá-la, mas importar ETR, considerando altos custos de produção, transporte e impacto ao meio-ambiente (JHA, 2014). Até a década de 1980, EUA, Brasil, Índia, Austrália e África do Sul concentravam a atividade de mineração e respondiam por mais de $60 \%$ da produção mundial de ETR. Dentre estes, apenas os EUA possuíam uma cadeia de suprimentos integrada, ou seja, produziam além dos minérios, óxidos, imãs e outros produtos com a presença dos elementos. Os demais eram responsáveis apenas pela exportação dos minérios e seus concentrados de baixo valor adicionado para a Europa Ocidental e o Japão (MEDEIROS E TREBAT, 2017). Em 2018, a China respondia pela produção em toneladas de 120.000, seguida da Austrália com 20.000, EUA com 15.000 e Brasil com apenas 1.000 , conforme pode ser visto no gráfico 2 : 
Gráfico 2 - Produção de ETR em 2018 - Dados em toneladas

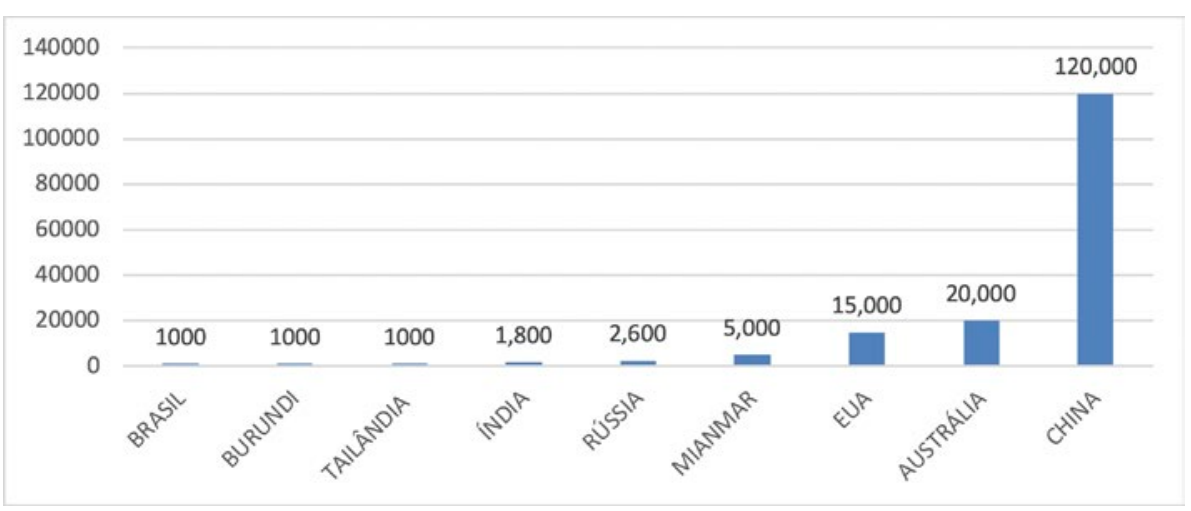

Fonte: Elaboração própria com base em USGS (2019).

Até o início da década de 1990, o principal processo de agregação de valor em óxidos e metais puros era feito em países desenvolvidos, e com baixa perspectiva de competição internacional (Cornell, 1993). Esse cenário foi alterado pela China, a partir de seus avanços na capacidade de processamento e refino dos ETR. Nessa época, a exploração de ETR tornou-se um setor oficialmente protegido e estratégico na China, com a proibição total do investimento estrangeiro na mineração dos elementos no país. Sendo assim, empresas estrangeiras só poderiam investir na separação, fundição e processamento dos ETR através de joint ventures com empresas chinesas aprovadas pela Comissão Nacional de Desenvolvimento e Reforma (NDRC - sigla em inglês) e pelo Ministério do Comércio (MOFCOM - sigla em inglês) (JEPSON, 2012). Em 2010, a China já era praticamente monopolista na oferta de ETR, com aproximadamente $90 \%$ da produção mundial (LAPIDO-LOUREIRO, 2013; USGS, 2013; SANTOS, 2014).

Conforme Rocio et al. (2013), a inserção da China no mercado internacional resultou de uma estratégia de longo prazo sistematizada após uma queda nos preços dos minerais no final da década de 1990. Desde então, a China aumentou sua produção em $450 \%$, saindo de 16.000 toneladas métricas para 73.000 toneladas métricas. Nos anos seguintes, a produção chinesa ampliou-se gradualmente, chegando a 2010 com 120.000 toneladas métricas (TSE, 2011), embora o consumo chinês tenha permanecido relativamente estável no período (TSE, 2011; MASSARI E RUBERTI, 2012). Consequentemente, olhando pelo lado da oferta do mercado, além de se tornar o maior produtor, a China adquiriu o papel de maior exportador mundial de ETR, conforme o gráfico 3. 


\section{Gráfico 3 - Principais países exportadores em 2017}

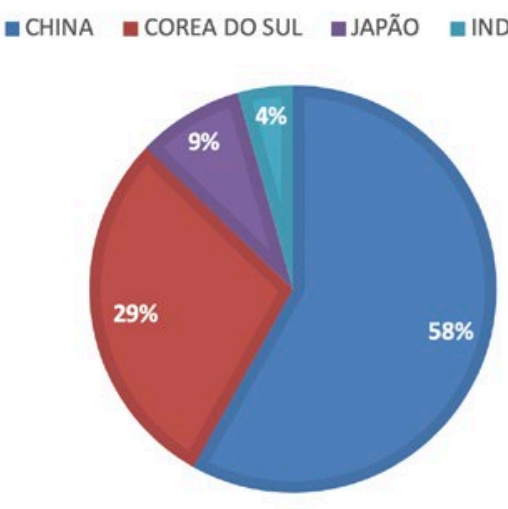

Fonte: Elaboração própria com base em Observatory of Economic Complexity (2017).

Com a concorrência entre as empresas e os governos locais que dependiam dos produtores para fornecer emprego e gerar receita para a economia local, a produção real da China excedeu o objetivo de produção do governo (CHINA STATE COUNCIL, 2006). Já nos anos 2000, os produtores chineses e o governo discutiram formas de controlar a produção e as exportações dos ETR, sob o discurso de conservar os recursos e proteger o meio ambiente. Nesse sentido, o governo intensificou a regulamentação e decretou o encerramento do funcionamento de minas ilegais dispostas em determinadas províncias, de modo que a produção de ETR permaneceu estável entre 2007 e 2011 (TSE, 2011). Em 2006, a China passou a instituir uma taxa de licenças para a exportação dos insumos, o que aumentou em $13 \%$ seus preços e reduziu a competitividade dos demais estados (MORRISON; TANG, 2012), conforme a Tabela 1. Em 2009, a China já possuía grandes estoques (ROCIO et al., 2013).

Tabela 1 - Produção, consumo e cotas de produção e exportação de terras raras na China, 2001- 2011 (dados em toneladas)

\begin{tabular}{|c|c|c|c|c|c|c|c|c|c|c|c|c|c|}
\hline Ano & & 2000 & 2001 & 2002 & 2003 & 2004 & 2005 & 2006 & 2007 & 2008 & 2009 & 2010 & 2011 \\
\hline \multirow{3}{*}{$\begin{array}{l}\text { Cotas de } \\
\text { Produção } \\
\text { Produção }\end{array}$} & MIIT & & & & & & & & & 119.500 & 110.700 & 89.200 & $\mathrm{NI}$ \\
\hline & MLR & 55.000 & $\mathrm{NI}$ & $\mathrm{NI}$ & $\mathrm{NI}$ & $\mathrm{NI}$ & $\mathrm{NI}$ & 86.620 & 87.020 & 90.180 & 87.620 & 89.200 & $\mathrm{NI}$ \\
\hline & (est.) & 73.000 & 81.000 & 88.000 & 92.000 & 98.000 & 119.000 & 133.000 & 12.000 & 125.000 & 129.000 & 120.000 & $\mathrm{NI}$ \\
\hline Consumo & (est.) & 19.000 & 20.000 & 22.000 & 30.000 & 34.000 & 52.000 & 63.000 & 73.000 & 67.700 & 73.000 & 77.000 & $\mathrm{NI}$ \\
\hline \multirow[t]{2}{*}{$\begin{array}{l}\text { Cotas de } \\
\text { Exportação }\end{array}$} & $\begin{array}{l}\text { Produtores } \\
\text { Domésticos e } \\
\text { Comerciantes* }\end{array}$ & 47.000 & 45.000 & $\mathrm{NI}$ & 40.000 & 45.000 & 48.010 & 45.000 & 43.574 & 34.156 & 31.310 & $22512^{* *}$ & $14.446 * * *$ \\
\hline & $\begin{array}{l}\text { Joint-ventu- } \\
\text { res estrangei- } \\
\text { ras* }^{*}\end{array}$ & $\mathrm{NI}$ & $\mathrm{NI}$ & $\mathrm{NI}$ & $\mathrm{NI}$ & $\mathrm{NI}$ & 17.570 & 16.070 & 16.069 & 15.834 & 16.845 & $7746 * * * *$ & $\mathrm{NI}$ \\
\hline
\end{tabular}

* Cotas de exportação em peso bruto de elementos Terras-raras a partir de 2005.

Englobam produtores e comerciantes nacionais e estrangeiros;

** Total da cota de exportação para 22 produtores domésticos e comerciantes;

** A cota de exportação para 2011 é para a primeira parcela de 31 produtores domésticos e comerciantes estrangeiros e Joint- ventures estrangeiras;

**** Total de cotas de exportação para produtores; NI: Não informado.

Fonte: Elaboração própria com base em Tse (2011). 
7. Tendo início ainda na década de 1990, o desenvolvimento de planos de produção para os ETR, que incluem desde as cotas de produção globais até as cotas para províncias individuais era de responsabilidade do Ministério da Terra e Recursos da China (MLR, sigla em inglês). Até então, era função dos governos provinciais gerir $\mathrm{e}$ atribuir cotas de produção a empresas mineradoras individuais. Todavia, uma quantidade excessiva da produção foi feita por mineiros que trabalharam sem licenças, utilizando tecnologia obsoleta e causando dados ambientais significativos (TSE, 2011). Em virtude disso, em 2008, a responsabilidade sobre os ETR foi transferida para o Ministério da Indústria, Informação e Tecnologia do Estado (MIIT, sigla em inglês) que passou a emitir uma cota de produção para

o país maior do que a que era então definida pelo MLR. A alteração na cota de produção ocasionou uma confusão entre os produtores dos ETR no final de 2010, isso porque ambos os Ministérios passaram a estabelecer a mesma cota de produção de terras raras
Desde 2000, as cotas de produção passaram a ser adotadas. No período indicado, as cotas maiores referem-se ao biênio 2008-2009. No segundo semestre de 2009, o Ministério Chinês da Indústria e Tecnologia da Informação (MIIT) ${ }^{7}$ informou a exportação de cinco tipos de ETR seria restringida, até 2014, embora tal ação não havia sido aprovada pelo Conselho de Estado Chinês (LEKOVITZ, MUSTAFAGA, 2010; REPORTLINKER, 2016). Como resultado, exportação de ETR caiu de 50.150 toneladas, em 2009, para 30.250 toneladas em 2010 (ANDREWS-SPEED, 2012).

Uma nota divulgada em 2011 pelo Wall Street Journal, de Xangai salientava que:

A China está acumulando reservas estratégicas de metais de terras raras, uma iniciativa que pode dar ao governo chinês um maior poder de influenciar os preços e ofertas mundiais de um setor que ele já domina [...]. A China não é a única a procurar estocar terras raras. Mas o país parece estar à frente dos outros países [...] (WSJ, 2011).

O Gráfico 4 traz a evolução dos países na produção mundial até o ano de 2013.

Gráfico 4 - Produção de compostos de TR (em toneladas de teor óxido)

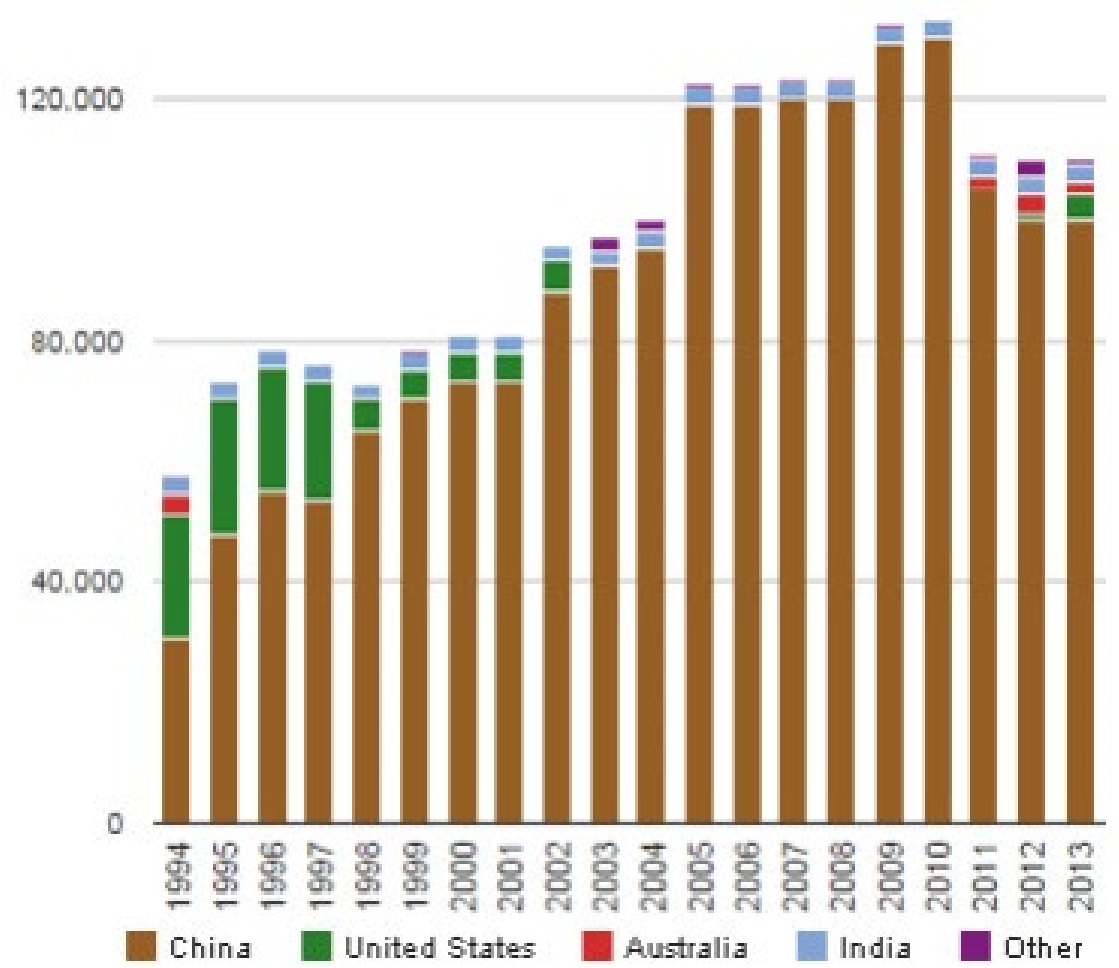

Fonte: GEOLOGY.COM (2015)

Humphries (2013) salienta que, como resposta a esse movimento, entre 2010 e 2011 houve um aumento no preço dos óxidos e metais de TR decorrente da restrição das exportações chinesas e da falta de capacidade de outros Estados de produzirem internamente o que antes importavam. Resultante desse cenário, e afetada pelo controle governamental sobre a exploração, a produção de ETR diminuiu nos anos seguintes, chegando em 83.400 toneladas em 2013, com uma queda de aproximadamente $16 \%$ 
em relação a 2012. Em relatório do Ministério da Economia, Comércio e Indústria (METI) do Japão nota-se que os preços de alguns ETR aumentaram drasticamente no país após a redução da cota de exportações chinesa. O preço do disprósio subiu de US\$250/ $\mathrm{kg}$ em abril de 2010 para US \$ $2.840 / \mathrm{kg}$ em julho de 2011, enquanto o preço do neodímio aumentou de US \$ 42/kg em abril de 2010 para US \$334/kg em julho $2011^{8}$.

O gráfico 5 ilustra as tendências da série histórica de preços, indicando, porém, que após esses picos, os preços caíram no primeiro semestre de 2012 e continuaram a cair no segundo semestre de 2013.

Gráfico 5 - Preços selecionados de óxido de terras raras entre 2009 e 2013. Dados em $\mathrm{U} \$ / \mathrm{Kg}$

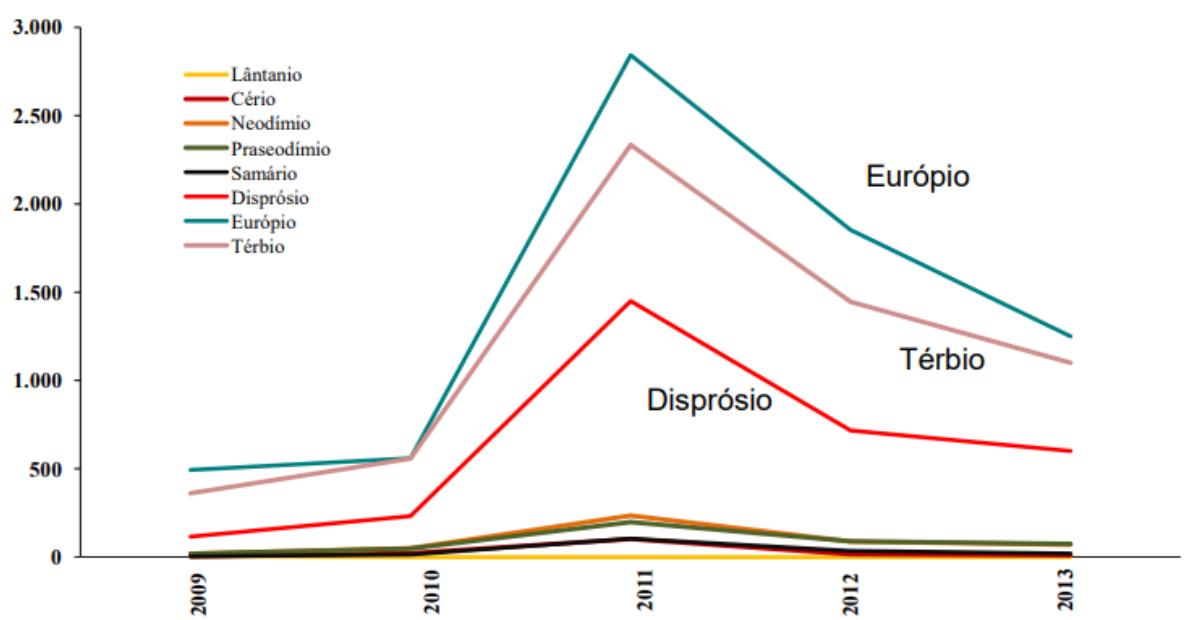

Fonte: Lynas Corporation (2013).

Diante do cenário sobre a trajetória da oferta mundial de ETR, a análise realizada indica o panorama da demanda de ETR. A gráfico 6 elenca os principais países importadores.

Gráfico 6 - Importação bruta de compostos de terras raras da China por país - dados de 2017

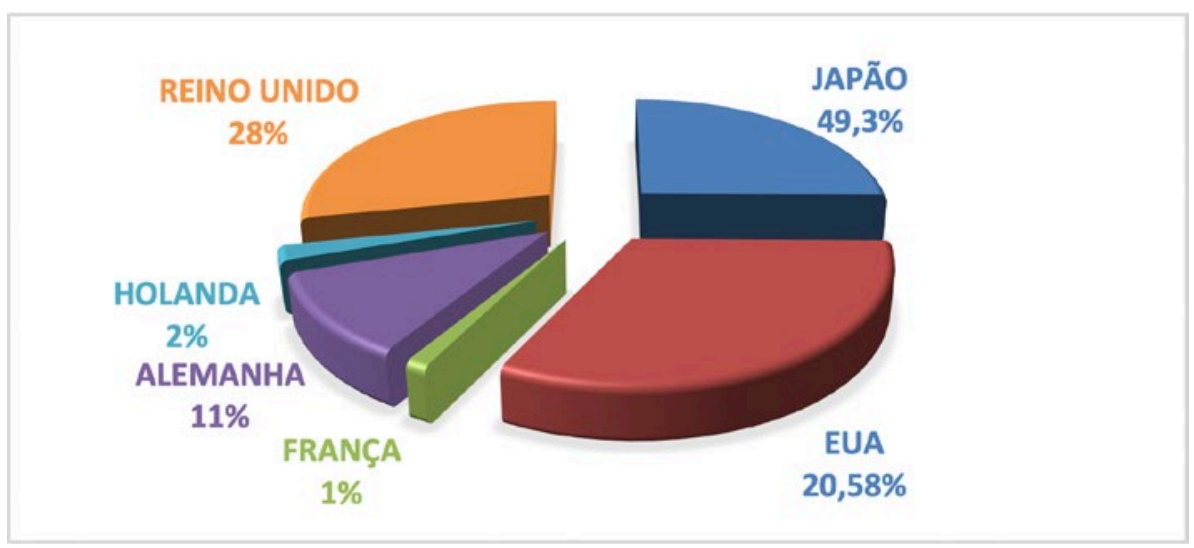

Fonte: Elaboração própria com base em Observatory of Economic Complexity (2017).

Nesse contexto, nota-se que o Japão e os EUA importavam, juntos, aproximadamente $70 \%$ dos compostos de TR chineses ${ }^{9}$. Segundo Gam-
8. A informação sobre o preço relacionado ao ano de 2011 foi retirado do Relatório CRS R42510 - Regime de Indústria e Exportação de TR da China: Economia e Implicações comerciais para os Estados Unidos, por Wayne M Morrison e Rachel Y. Tang. Os preços referentes ao ano de 2012 e 2013 foram obtidos da Lynas Corp. Relatório Trimestral, junho de 2013.

9. Conforme Schmid (2019), destaca-se que desde então, o Japão tem tentado ativamente garantir seu suprimento fora da China, a fim de reduzir sua dependência. Com base em uma análise da evolução do mercado e das atividades do Japão nos últimos anos, 0 autor sugere algumas lições aprendidas são aplicadas aos EUA, que atualmente enfrentam incertezas semelhantes. 
bogi (2015), os principais destinos dos ETR importados da China pelos EUA estão direcionados para a produção doméstica estadunidense de catalisadores (60\%); aplicações e ligas metalúrgicas (10\%); ímãs permanentes (10\%); polimento de vidro (10\%); e outros (10\%). Nesse sentido, é possível compreender a lógica da estratégia chinesa em investir na capacidade de processamento, refinação e fabricação de produtos finais para atender a demanda crescente do comércio internacional (HUMPHRIES, 2013). Após consolidada a estratégia de exportar matéria prima, a China passou a outra fase na tentativa de agregar valor à sua pauta de exportação (MELO, 2017). Todos os projetos que envolviam a mineração e fundição dos ETR, independentemente do tamanho, passaram a exigir a aprovação da Comissão de Desenvolvimento e Planejamento do Estado (SDPC, sigla em inglês). Como afirma Leite et al. (2017) a política externa chinesa no que concerne à posse e gestão dos ETR apresentou um viés mais pragmático. O abastecimento do mercado foi subordinado aos interesses do desenvolvimento industrial doméstico e a uma posição mais assertiva no mercado internacional.

De acordo com Coppel (2011), a situação norte-americana consistia em uma dependência das aquisições de metais derivados de ETR para o fornecimento de insumos essenciais para sua industria bélica. Com efeito, observa-se a situação norte-america agravar-se com sua maior vulnerabilidade resultante da dependência da oferta destes insumos, principalmente, após o anúncio de restrição às exportações feito pela China. Vale mencionar, entretanto, que o reflexo da ação chinesa não atingia unicamente o setor de defesa dos EUA. Assim como no setor industrial chinês, estes insumos são de extrema importância para os setores industriais de alta tecnologia, influenciando países como EUA, Japão, e alguns países da UE. Logo, não apenas criam vulnerabilidade a países que demanda estes insumos, como EUA, Japão, paises da UE, como também colocam em risco o desenvolvimento produtivo do setor de maior valor adicionado destes países (LEITE; ARAÚJO, 2015).

Para além da demanda externa, há que se considerar a demanda da própria economia chinesa. O crescimento da China no setor tecnológico com a utilização dos ETR promoveu o crescimento do país no setor científico e tecnológico, criando novos negócios com implicações importantes para o aumento da produtividade (IEDI, 2011). A demanda interna de ETR tem evidenciado que as políticas adotadas obtiveram êxito no estímulo ao crescimento da produção de alto valor agregado. Ao se lançar no mercado das TR, a China se expôs a maiores riscos e acentuou alguns pontos de vulnerabilidades próprias, dentre as quais destaca-se a questão da poluição ambiental e os altos custos sociais, econômicos e políticos decorrentes dessa.

Agora, passando para as relações entre oferta e demanda, busca-se caracterizar o tipo da relação comercial existente entre a China e seus parceiros comerciais a partir do cálculo de um indicador de interdependência. De acordo com Keohane e Nye (1989), para mensurar uma relação de interdependência econômica, o grau de sensibilidade comercial é o principal meio para quantificar o quanto um determinado ator sofre de imediato com os custos de uma alteração no comportamento de seu par- 
ceiro comercial. No caso dos ETR, a intensidade comercial estabelecida entre a China e os principais demandantes dos recursos naturais estratégicos pode ser calculada a partir da variação percentual da quantidade importada de ETR sobre a variação percentual dos preços dos elementos. Aqui, quanto maior o valor, maior será o grau de sensibilidade na relação.

O cálculo da elasticidade preço da demanda pode corroborar a posição de monopolista de ETR assumida pela China.

$$
E P d: \frac{\Delta Q}{Q} \times \frac{P}{\Delta P} 10
$$

Segundo o relatório Research in China (2014), em 2009, a média de preço de oito elementos de terras raras esteve em volta de US\$127,44, e nesse período a China foi responsável pela exportação de aproximadamente 50.150 toneladas métricas. Já no ano seguinte, em 2010, a média de preços aumentou $47 \%$, chegando a US $\$ 188,13$ e a exportação caiu cerca de 39,68\%, chegando a 30.250 toneladas métricas. Nesse período, a elasticidade preço da demanda, tem-se que entre 2009 e 2010, a demanda mundial correspondeu a $|-0,83|$, sendo, portanto, inelástica, ou seja, o mercado consumidor não tinha tantas alternativas para responder com redução na demanda proporcional ao aumento de preço.

O caso do Japão é ilustrativo. Em valores estimados pelo Observatory of Economic Complexity (OEC), o governo japonês pagou por sua importação de ETR U\$65,1 milhões, em 2009 e S\$148 milhões em 2010, ao passo que o volume de suas importações só aumentou 1\%, conforme o gráfico 7. No caso dos EUA, em 2009 pagaram U $\$ 3,72$ milhões à China por $72 \%$ dos ETR que importaram. Em 2010, um aumento de mais de $250 \%$ no valor de importações (de US $\$ 3,72$ milhões para US\$13,3 milhões), correspondente a, apenas, $17 \%$ de aumento na quantidade percentual importada $(72 \%$ para $84 \%)$. No tocante ao bloco europeu, dados sobre os valores pagos pelas importações de ETR não se encontram disponíveis no OEC (2016). Todavia, estima-se que a quantidade importada dos elementos chineses pelo bloco, em 2009, correspondeu a cerca de $80 \%$, enquanto em 2010, a quantidade importada pelo bloco aumentou para $87,1 \%$.

Ainda de acordo com o Research in China (2014), nos anos seguintes, entre 2010 e 2011, o preço dos ETR no comércio internacional disparou, chegando a US\$ 921,01 em junho de 2011, um aumento de $92,10 \%$ em relação ao ano anterior. O relatório salienta que a quantidade estimada para exportação chinesa em 2011 se assemelhava ao ano anterior, representando cerca de 30.260 toneladas métricas, considerando que, em 2011, pela primeira vez seriam incluídas as ligas de ferro na cota de exportação.

Paralelo a esse cenário, houve uma redução de $50 \%$ na quantidade exportada em relação a 2010, chegando a 15.000 toneladas métricas. A explosão dos preços dos insumos foi resultado do aumento da demanda mundial e das restrições à exportação adotadas pelo governo chinês. Nesse caso, a elasticidade-preço da demanda mundial correspondeu a $|-0,12|$, altamente inelástica. De acordo com o OEC (2016), o governo japonês pagou aproximadamente $\$ 573$ milhões pelas importações de ETR da China, enquanto a quantidade importada foi reduzida de $81 \%$ em 2010 para 78\% em 2011. Com os EUA a situação não foi muito diferente. Pagando 
em 2011 aproximadamente $\$ 50,6$ milhões, os norte-americanos viram a quantidade importada diminuir de 84\% em 2010 para $75 \%$ em 2011.

Por seu turno, os europeus também sentiram o peso da redução da cota de exportações da China, em dados do OEC (2016) a quantidade importada pelo bloco correspondeu a $46 \%$, uma diferença de aproximadamente 40\% em relação ao ano anterior. Entre 2011 e 2012, houve um relaxamento nas medidas restritivas à exportação. O ano de 2012 começou com os preços dos ETR estabilizados em 531,92 US\$, uma redução de $38,91 \%$ em relação ao ano anterior. Já a quantidade exportada para o globo correspondeu a aproximadamente 16.300 toneladas métricas no mesmo ano. Nesse cenário, os cálculos realizados apontam uma demanda inelástica ainda pouco sensível à variação dos preços. Em números exatos, essa demanda mundial correspondeu a $|-0,20|$ (RESEARCH IN CHINA, 2014).

Em 2012, o Japão pagou pelas importações de ETR menos da metade do valor pago em 2011. Em valores exatos os japoneses importaram $76 \%$ de seus elementos oriundos da China pelo preço de $\$ 235$ milhões, enquanto que os norte-americanos importaram $84 \%$ dos elementos pelo valor de $\$ 18,1$ milhões. Já os europeus continuaram diversificando as fontes de exportação dos ETR, reduzindo, consequentemente, a quantidade importada da China para apenas 18,7\% em 2012 (RESEARCH IN CHINA, 2014).

Por fim, os últimos dados disponibilizados pelo relatório em questão se referem ao ano de 2013 quando houve uma queda de 14,02\% nos preços dos ETR em relação ao ano anterior, chegando a 391,7 US\$. Por seu turno, a quantidade exportada pela China teve um aumento considerável em relação a 2012, chegando a 22.500 toneladas métricas. Nesse cenário, a demanda continuou apresentando sinais de inelasticidade, correspondendo a $|-0,001|$, ou seja, a variação no preço não afetou em quase nada a quantidade demandada nesse período (OEC, 2016; RESEARCH IN CHINA, 2014).

O Japão seguiu o exemplo europeu e pagou menos pelas importações dos ETR oriundos da China, chegando a aproximadamente \$106 milhões, enquanto a quantidade importada pelo país também foi reduzida para $51 \%$. Os EUA não ficaram atrás na busca pela diversificação das exportações dos minérios estratégicos. Em 2013 os norte-americanos pagaram cerca de \$5,06 milhões pelas importações, enquanto a quantidade importada correspondeu a apenas $44 \%$. Não obstante, nesse último cenário os europeus voltaram a aumentar a cota de importações dos ETR, chegando a $21,1 \%$, um aumento de $2,4 \%$ em relação ao ano anterior (RESEARCH IN CHINA, 2014).

O gráfico 7 ilustra a evolução dos valor e quantidade de importações de ETR chinês pelo Japão e EUA e a tabela 2 traz os cálculos dos índices de elasticidade-preço de Japão e EUA, indicando a vulnerabilidade desses países mediante os aumentos de preço. 
Tabela 2 - Cálculo do Indicador Elasticidade-preço demanda

\begin{tabular}{|l|l|l|l|l|l|l|}
\hline & Ano & 2009 & 2010 & 2011 & 2012 & 2013 \\
\hline & Valor Importações da China (em milhões de dólares) & 65,1 & 148 & 573 & 235 & 106 \\
\hline Japão & Volume percentual de suas importações provenientes da China (em \%) & 80 & 81 & 78 & 76 & 51 \\
\hline & Elasticidade-preço da demanda & - & 0,008 & $-0,010$ & 0,034 & 0,455 \\
\hline & Valor Importações da China (em milhões de dólares) & 3,72 & 13,3 & 50,6 & 18,1 & 5,6 \\
\hline EUA & Volume percentual de suas importações provenientes da China (em \%) & 72 & 84 & 75 & 84 & 44 \\
\hline & Elasticidade-preço da demanda & - & 0,047 & $-0,032$ & $-0,140$ & 0,579 \\
\hline
\end{tabular}

Fonte: Elaboração própria.

Gráfico 7- Evolução de valor de importações preço da demanda dos ETR entre 2009 e
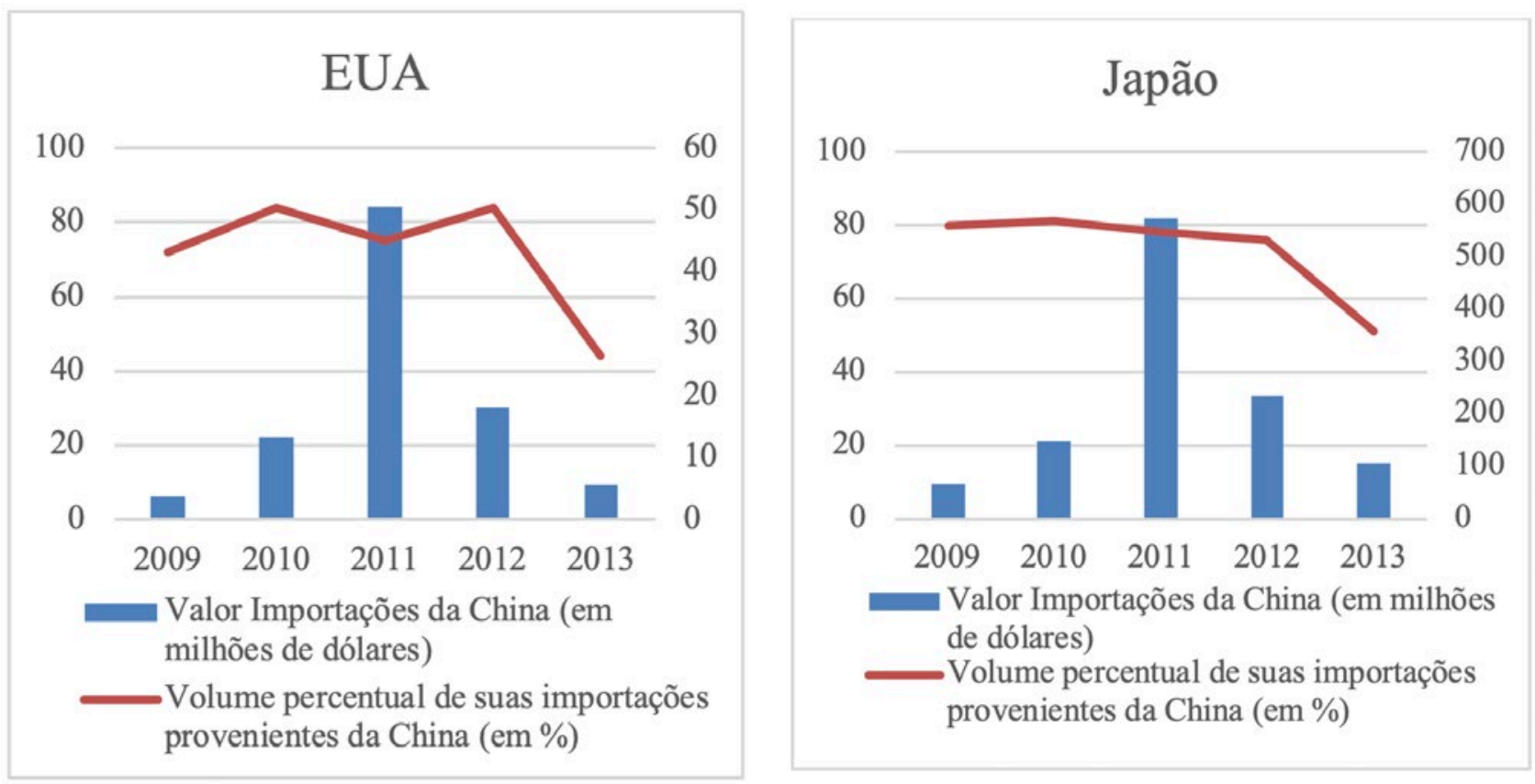

Fonte: Elaboração própria.

Da ação à reação: o caso das ETR na OMC

Com o monopólio de muitos minérios estratégicos, a China passou a ser vista como uma eminente ameaça comercial a muitos outros países, desenvolvidos ou em desenvolvimento. O poder de barganha logrado pela China ao possuir o controle dos recursos estratégicos tornou-se alvo de discussões e de um painel no Órgão de Solução de Controvérsias (OSC) da Organização Mundial do Comércio (OMC). A dinâmica dos preços dos insumos, particularmente daqueles cuja demanda tende a ser constante, associada à política de controle e restriçõs praticada pela China, fez com que o ex-presidente norte-americano, Barack Obama, declarasse, em um discurso oficial em meados de 2014, que os produtores chineses estariam obtendo vantagens competitivas no mercado internacional. Este se daria por meio da utilização da criação de poder de monopólio de insumos e 
10. Medidas antidumping têm como objetivo neutralizar os efeitos danosos à indústria nacional causados por determinadas importações, por meio de alíquotas específicas pelo uso de uma política de competição injusta, trazendo perdas ao setor produtivo norte-americano. Ainda segundo Barack Obama (SANTOS, 2014), que não cita o termo poder de monopólio, estaria ocorrendo concentração dos ganhos por parte da China em detrimento de setores produtivos norte-americanos (LEITE; ARAÚJO, 2015).

Além do Estados Unidos, intensificaram-se as pressões de países como o Japão contra a restrição voluntária às exportações dos elementos de terras raras. Nessa conjuntura de renascimento do protecionismo seletivo chinês, destacam-se medidas de caráter excepcional e discriminatório previstas na adesão da China à OMC (2001), a exemplo da possibilidade de aplicar salvaguardas especiais contra as exportações, ou prorrogar a não aplicação da economia de mercado em processos antidumping ${ }^{10}$. Considera-se, de fato, que a política praticada pela China é semelhante a outros casos históricos de potências emergentes na proteção de suas atividades nacionais.

Mesmo assim, o tema das ETR foi levado à OMC. A acusação feita à China no âmbito da OMC "é que o país tem tentado manter a condição de dependência e carência dos elementos nos países que precisam dele para manter e dar continuidade a seus parques industriais" (LEITE; ARAÚJO, 2015). Segundo França (2012), e como já ressaltado acima, para os EUA estes metais são recursos críticos para setores industriais estratégicos: o setor de alta tecnologia e a industria de defesa. Portanto, a preocupação derivada da restrição à compra destes insumos torna-se mais aguda quando se observa a cadeia de produção dependente destes insumos. Além disso, de acordo com a European Commission (2011), diferente do que ocorre com matérias-primas que são comercializadas na bolsa de valores de Londres, os ETR não são comercializados dessa forma, o que torna a negociação do bloco europeu com o principal ofertante das commodities menos transparente.

A China apresentou à época uma contestação à demanda encabeçada por EUA, Japão e países da UE. Seu argumento foi fundamentado em uma política ambiental e na proteção de seus recursos naturais. Usou-se na construção da contra-argumentação que a China buscava migrar para um modelo de desenvolvimento sustentável, logo sua política de restrição às exportações de ETR estaria associado a uma guinada para um desenvolvimento "limpo". Conforme consta no documento de 2012 (CHINA, 2012), não houve "má fé" por parte da China e de seus representantes políticos, notadamente seu Primeiro Ministro, e qualquer medida tomada possuía a "intenção de proteger as indústrias domésticas em detrimento dos seus compromissos com comércio exterior” (LEITE; ARAÚJO, 2015).

A abordagem utilizada por Beijing para a regulamentação internacional dos recursos estratégicos de TR deve ser entendida no contexto da experiência da China no direito internacional, uma vez que intuindo proteger seus recursos, ao mesmo tempo em que desenvolvia internamente sua indústria, a China estabeleceu mediante um documento que entrou em vigor em $1^{\circ}$ de agosto de 2002 que o estabelecimento de empresas estrangeiras para mineração dos insumos seria proibido.

Hurst (2010) sustentava que o objetivo da política implementada pela China consistia em expandir, integrar e desenvolver a industria do- 
méstica que possuía como insumo os ETR. A tendência, mantida esta meta era, além de exercer controle da oferta de insumo e da produção de mercadorias de alto valor adicionado, mas também gerar um mecanismo de inserção internacional na industria dos insumos e de mercadorias produzidas com base na sua farta disponibilidade destes recursos. Assim, torna-se possível para a China atrair investidores externos para construir fábricas no país. Estas já no perfil "desenvolvido" de industria, controlando parte significante do processo produtivo e gerando mercadoria de melhor condições no mercado internacional e para o desenvolvimento produtivo chinês. A estratégia de atração de investidores estrageiros para a produção de derivados dos ETR foi direcionada para três setores: processamento intensivo, novos materiais e produtos aplicados (GERALDO, 2012. LEITE;ARAÚJO, 2015).

Desse modo, o que se inicia como um planejameto de desenvolvimento doméstico de um setor industrial sustentado na abundância de um tipo específico de recurso natural (ETR) resultou na criação e desenvolvimento de uma complexa e integrada cadeia produtiva de desdobramentos que influenciaram o mercado internacional. A China passou então a controlar as exportações de terras raras. Em meados de 2011 observou-se uma redução mais acentuada das exportações, estratégia iniciada no ano de 2005. A redução na cota de exportações desde meados de 2005, indica uma "estratégia de barreiras à exportação visando, de acordo com a narrativa adotada pelo Estado" (LEITE; ARAÚJO, 2015), "à garantia de suprimento estável, ainda que a um alto custo relativo de produção" (LIMA, 2011).

Santos (2014) ressalva que o controle dos insumos de ETR pelo governo chinês tende a gerar implicações de ordem econômica, política e de segurança, tomando simultaneamente os ambientes doméstico e internacional. Santos (2014) corroborando o entendimento dos autores deste artigo, ressalta a importância dos insumos derivados de ETR para inúmeros projetos de defesa e segurança nacional. Isso seria uma política estratégica de projeção de poder, não uma questão apenas de cunho comercial. A estratégia deu-se com o "pressuposto de que a China não era só responsável pela concentração de reservas de terras raras, mas também detém total domínio do processo de manufaturamento, com importantes repercussões para a indústria bélica” (LEITE; ARAÚJO, 2015; ROBINSON, 2011).

Consequencia da postura adotada pela China é a oscilação de preços provocada pela alteração na cota de exportação para os países consumidores dos insumos. Dada a estratégia adotada pela China, observa-se o aumento da dependência e carência dos países, especialmente os desenvolvidos, e seus centros industriais da importação dos recursos (insumos) essenciais para manutenção de suas indústrias militares e dos setores de produtos finais de alta tecnologia (base do desenvolvimento destas economias). Logo observou-se mudanças expressivas na configuração das agendas nacionais de países que não possuem reservas ou possuem reservas não exploradas.

Este processo teve como resultado as reclamações destes países junto à OMC via OSC (OMC, 2015).

Em março de 2012 foi proposta uma disputa na OMC contra a China. Os demandantes alegaram que a China descumpriu os artigos VII, VIII, $\mathrm{X}$ e XI do GATT 1994, além dos parágrafos 2(A)2, 2(C)1, 5.1, 5.2, 7.2, 8.2 e 11.3 
da Parte I do Protocolo de Acesso da China à OMC, bem como das obrigações firmadas no parágrafo 1.2, Parte I do mesmo Protocolo (REIS, 2017).

Segundo relatório (OMC, 2015), o litígio proposto por EUA, União Europeia e Japão contra a China dizia respeito as restrições impostas pela última à exportação de ETR. De acordo com os demandantes, o objetivo da China ao reduzir significantemente a cota exportada dos elementos nada mais era do que privilegiar o fornecimento exclusivo dos insumos para suas próprias indústrias, de modo que essas poderiam usar tal vantagem para produzir bens tecnológicos, angariando, por conseguinte, uma maior competitividade no mercado internacional dos elementos. A China se defendia com o argumento de que as restrições eram necessárias para conservar seus recursos não-renováveis, e reduzir os efeitos colaterais causados pela exploração dos elementos em seu solo (OMC, 2015).

As conclusões do painel, em 2014 podem ser traduzidas da seguinte forma:

\begin{abstract}
(i)Deveres de Exportação: Sob seu Protocolo de Adesão à OMC China tem o direito de aplicar direitos de exportação para apenas os 84 produtos listados em um anexo ao protocolo. Estes materiais não estavam nessa lista. Por isso a China não pode invocar o artigo XX do GATT (Acordo Geral sobre Tarifas e Comércio) para estes materiais sob quaisquer condições;

(ii)Quotas de Exportação: Quotas de exportação da China não podem ser justificadas sob o Artigo XI: 2 (a) do GATT como sendo aplicadas temporariamente para aliviar uma escassez crítica de produtos alimentares ou outros produtos essenciais. Nem poderiam ser justificadas as quotas nos termos dos artigos XX (b) ou XX (g), que se referem, respectivamente, para a necessidade de "proteger humana, animal ou vegetal vida ou a saúde" e à "conservação dos recursos naturais não renováveis, se tais medidas são feitas aplicadas juntamente com restrições à produção ou consumo interno" (ANDREWS-SPEED, 2012, p. 1, tradução nossa).
\end{abstract}

Em 2015, um novo relatório foi emitido sobre a situação dos ETR no mundo. A atualização desse relatório salientava o texto introdutório do artigo XX advertindo que medidas restritivas no comércio internacional não devem constituir "um meio de discriminação arbitrária ou injustificável entre países" (OMC, 2015). Logo, os argumentos apresentados pela maior ofertante e réu do painel, a China, foram refutados pela OMC e a tríade encerrou o painel como vencedora da lide.

Todavia, reforçando sua preponderância no setor, a China continuou buscando ultrapassar com sucesso os países mais avançados da indústria das commodities estratégicas (MANCHERI, 2014). Como salienta Melo (2017, p. 236), a derrota chinesa no painel da OMC e o redução das restrições às exportações impostas pela China impactaram na redução dos preços após seu período de pico (2011). Contudo, não se espera que este preço caia mais vistoa tendência mundial de elevação do consumo destes insumos. O cenário fica mais incerto quando se insere na equação de análise a guerra comercial entre EUA e China, intensificada em 2019.

Naturalmente, a postura chinesa produziu uma série de efeitos colaterais. Após anunciar e aplicar as restrições sobre a cota de exportação, a China despertou a desconfiança de seus principais demandantes de matérias-primas. Até que ponto ainda era confiável manter-se dependente das importações chinesas? 
Sobre esse questionamento, não se pode negar que a derrota da China no painel da OMC sobre os ETR gerou sérias discussões sobre temas importantes, como soberania e independência dos países membros da organização no tocante ao uso de seus recursos naturais. Ademais, essa resposta tornou-se ainda mais clara a partir da própria reação do comércio internacional, quando os atores, antes dependentes integralmente das exportações chinesas, passaram a diversificar suas fontes. Logo, além de inédito no comércio internacional dos ETR, esse processo de readaptação pode ser observado também por uma ótica estratégica para as relações internacionais.

Por seu turno, ainda em dezembro de 2014, China e EUA chegaram a um acordo sobre o caso dos ETR, com a primeira se comprometendo a reformar sua política para o setor até maio de 2015. Essa mudança de posicionamento adotada pela China representou um passo na direção do encerramento do conflito. Ainda assim, à época, analistas salientaram que, apesar da mudança acordada entre ambos os Estados, a China iria seguir exercendo um intenso controle sobre o mercado dos metais estratégicos, administrando-o conforme seus interesses.

Curiosamente, apesar de ter se comprometido a encerrar as restrições até maio de 2015, em janeiro de 2015 a China confirmou a eliminação das restrições à exportação dos 17 elementos estratégicos. Essa medida foi anunciada após uma disputa que durou dois anos na OMC. Consequentemente, embora a China continue mantendo seu controle sobre o mercado dessas commodities, o Estado se comprometeu a não limitar o volume das exportações (LEITE; ARAÚJO; PAUTASSO, 2017).

Contudo, após a disputa na OMC houve o florescimento de um robusto mercado clandestino dos ETR. De fato, é provável que as restrições chinesas tenham contribuído para tal cenário. Todavia, desde meados de 2014, por meio de medidas anunciadas pelo governo, a China já demonstrava a intenção de aumentar seu controle sobre o mercado através de uma maior concentração no setor. Era incerto, entretanto, qual seria o impacto dessa política chinesa sobre o mercado das commodities e sobre o conjunto de reações da política internacional nos anos seguintes.

Com as retaliações por parte dos países demandantes do painel da OMC, e de teor igualmente crítico, a China, ao distanciar-se do cenário analisando-o de forma estratégica, aprimorou a ideia de, quando necessário, mudar suas jogadas no tabuleiro geopolítico, adequando-se ao cenário imposto. A partir de uma releitura de um cenário que se encontra em constante mutação, a China concebeu e implementou ao longo do recorte temporal e para além dele, um plano estratégico que tem levado o país a controlar o atual mercado mundial de minérios estratégicos de terras raras, embora, conforme Schimd (2019) mostre, seus maiores importadores tem buscado desenvolver alternativas ao fornecimento chinês.

Considerações Finais

O caso das ETR é emblemático na estratégia chinesa em traduzir sua ascensão econômica em geopolítica, ancorada em sua política industrial e comercial. Embora a China esteja consolidada como o país que 
mais ampliou o grau de atração de investimentos diretos estrangeiros, desde os anos 1990, o investimento agregado no país no setor de exploração e refino das commodities ainda é maciçamente doméstico.

A utilização dos ETR como instrumento de poder econômico da China pode ser justificada com base em três posicionamentos do próprio Estado, quais sejam: 1. Sua preocupação pertinente com o meio ambiente, justificada pelos altos índices de poluição e de enfermidades acometidas decorrentes dessa; 2 . O viés econômico oriundo da comercialização dos elementos em sua forma final, como produtos altamente tecnológicos - a China deixaria de ser exportador primário, e passaria a comercializar produtos com porcentagens dos elementos em seu molde final, e; 3. O viés político resultante desse protecionismo, variável importante no que diz respeito ao poder de barganha oriundo da monopolização dos ETR e o uso dos mesmos como moeda de troca. Em suma, deter o monopólio e a produção dos ETR mostrou-se como o melhor procedimento a ser adotado para exercer poder promovendo uma influência real sobre o comportamento dos demais Estados que dependem das exportações chinesas dos metais estratégicos.

Essa visão longínqua tem produzido resultados para a indústria chinesa. Todavia, o maior desafio a ser enfrentado hoje pela China ainda é conseguir penetrar nos mercados mais sofisticados de eletrônicos, energia verde, defesa e outros setores estratégicos. Observa-se que em alguns casos isso já aconteceu mediante o progresso alcançado nos setores de computação e no mercado de energia eólica, onde o controle chinês sobre o fornecimento de TR tem oferecido vantagens corporativas. Destarte, outros progressos ainda dependem da tendência tecnológica chinesa, e, o mais importante, de como o resto do mundo lidará com essa tendência. Até porque, assim como o Estado chinês tem buscado aproveitar sua base de matérias-primas de terras raras para promover o avanço técnico em setores estratégicos, os países dependentes de terras raras têm buscando fontes não-chinesas e investindo em tecnologias menos dependentes de terras raras. Após o anúncio das restrições, o Japão, por exemplo, passou a dedicar um enorme esforço para abrir novas fontes de fornecimento contra a contingência chinesa (SCHIMID, 2019).

O resultado desse cenário é que com as retaliações por parte dos países demandantes do painel da OMC, e de teor igualmente crítico, a China distanciou-se do cenário, analisando-o de forma estratégica. A partir de uma releitura de um cenário que se encontra em constante mutação, a China concebeu e implementou um plano estratégico que tem levado o país a controlar o atual mercado mundial de minérios estratégicos de terras raras e continuar estável em seu posto de monopolista na exportação dos elementos.

Curiosamente, embora o quadro ambiental chinês aponte para uma reversão do modelo de desenvolvimento, a China tem buscado avançar na superação das contradições ambientais que as circundam. Entretanto, nessa perspectiva a dinâmica do desenvolvimento e a imprevisibilidade do progresso tecnológico com vistas à inversão de habilidades recomendam certa cautela no desenho de um cenário ambiental sombrio para os próximos anos. 
Destaca-se, assim, que a China perseguiu uma estratégia clássica de desenvolvimento pioneira de outras grandes potências industriais, não tem se limitando a exportações de recursos naturais, visando ampliar seu poder econômico e geopolítico, buscando obter vantagens competitivas em indústrias de alto valor agregado. Nesse cenário, as divergências com outras potências têm sido habilmente manobradas, uma vez que o Estado vem arquitetando estratégias de adaptação às transformações geopolíticas inerentes a conjuntura apresentada - na qual se inclui um investimento considerável por parte de outros Estados que possuem reservas de ETR em sua exploração e comercialização, ainda que essa medida demande um planejamento de longo prazo por parte destes.

Referências

ALEXANDER, Simões. The Observatory of Economic Complexity. [201-]. Disponível em: https://atlas.media.mit.edu/en/. Acesso em: 29 jan. 2018.

ANDREWS-SPEED, Philip. The Rare Earth Case against China at the WTO: Who Wins? Transatlantic Academy, 2012.

CARDOSO, S; PAZETTI, J; SANTOS, R. Terras raras: a China e o papel da governança global. Electronic Journal of Economic Sociology Studies, v. 4, n. 2, 2014.

CHINA STATE COUNCIL. Instruction for mineral resource development. Beijing, China, 2006.

CHINA. Embaixada da República Popular da China no Brasil. China responderá queixa sobre terras raras diante da OMC. Brasília, 2012.

COLLIER, P; HOEFfleR, A. Greed and Grievance in Civil War. Oxford Economic Paper, v. 56, n. 42004

COPPEL, E. Rare Earth Metals and U.S. National Security. American Security Project, 2011.

CORNELL, D.H. Rare earths from supernova to superconductor. Pure and Applied Chemistry, v. 56, n. 12, 1993.

EGLIN, M. 'China's entry into the WTO with a little help from the EU'. International Affairs, 1997. EUROPEAN COMMISSION. Tackling the challenges in commodity markets and on raw materials. Brussels, 2011. Disponível em: http://eur-lex.europa.eu/LexUriServ/LexUriServ. do?uri=COM:2011:0025:FIN:en:PDF. Acesso em: 01 jul. 2017.

FRANÇA, Martha. Terras que Valem Ouro. Disponível em: http://www.cetem.gov.br/clipping/terrarara-unesp-ciencia.pdf\&gt. Acesso em: 25 abr. 2017.

FRIEDEN, Jeffry A; LAKE, David A. International political economy: perspectives on global power and wealth, 2000.

FUSER, I. Os recursos energéticos e as teorias das relações internacionais. In: HAGE, J.A. (org.). A energia, a política internacional e o Brasil. São Paulo: Instituto Memória, 2010.

GAMBOGI, Joseph. Mineral Commodity Summaries. United States: U.s. Geological Survey, 2015.

GERALDO, Michelly. A securitização da política energética nas relações internacionais a partir dos anos 1970. 2012. Disponível em: http://www.ufrgs.br/sebreei/2012/wp-content/ uploads/2013/01/Michelly-Sandy-Geraldo.pdf\&gt. Acesso em: 20 nov. 2017.

GEOLOGY.COM. The Geology of Rare Earth Elements. Republished from: The Principal Rare Earth Elements Deposits of the United States, USGS Scientific Investigations Report 2010-5220. Disponível em: https://geology.com/usgs/ree-geology/. Acesso em: set. 2019.

GILPIN, Robert. War and change world politics. New York: Cambridge University, 1981.

GONÇALVES, R. Economia Política Internacional. Rio de Janeiro: Campus, 2005.

HUMPHRIES, M. Rare Earth Elements: The Global Supply Chain. Washington: Congressional Research Service, 2013.

HURST, C. China's Rare Earth Elements Industry: What can the west learn? Institute for the Analysis of Global Security - IAGS, Washington, 2010. 
IEDI. Uma comparação entre a agenda de inovação da China e do Brasil. Rio de Janeiro: IE/ UFRJ, 2011.

JEPSON, N. A 21st century scramble: South Africa, China and the rare earth metals industry. Occasional Paper,$n^{\circ} 113$, 2013. Disponível em: https://scholar.sun.ac.za/handle/10019.1/21176. Acesso em: mai. 2020.

JHA, Saurav. China's Rare Earths Advantage. 2014. Disponível em: http://thedi-plomat. com/2014/04/chinas-rare-earths-advantage. Acesso em: 29 nov. 2017.

KALANTZAKOS, Sophia. China and the geopolitics of rare earth. NY: Oxford University Press, 2018.

KAY, Cristobál. Teorias estruturalistas e teoria da dependência na era da globalização. In: MARTINS, Carlos Eduardo; SOTELO VALENCIA, Adrian (Org.). A América Latina e os desafios da globalização: ensaios dedicados a Ruy Mauro Marini. São Paulo: Boitempo, 2009.

KEOHANE, Robert O.; NYE JR, Joseph S. Power and Interdependence. International Organization, v. 41, n. 4, 1989.

KLARE, Michael. The new geopolitics of energy. New York: The Nation, 2008. Disponível em: http://www.thenation.com/article/new-geopolitics-energy. Acesso em: 14 nov. 2017.

KREMER, J. Towards a new Understanding of Structural Power - Theoretcal Consideration. Edinburgh: International Studies Conference, 2012.

LAPIDO-LOUREIRO, F. E. O Brasil e a reglobalização da indústria das terras raras. CETEM / MCTI. Rio de Janeiro, 2013.

LEITE, A.C.; ARAUJO, M.C.; PAUTASSO, D. O poder de barganha político chinês e o reordenamento político e econômico global: a macroestratégia e a inversão de habilidades no caso das terras raras. Brazilian Journal of International Relations, v. 6, p. 307-225, 2017.

LEITE, A.C.C. O projeto de desenvolvimento econômico chinês - 1978- 2008: a singularidade de seus fatores políticos e econômicos. 2011. 219 f. Tese de (Doutorado) - Programa de Pós-Graduação em Ciências Sociais, Pontifícia Universidade Católica de São Paulo, São Paulo, 2011.

LEITE, A.C.C; ARAÚJO, M.C. Elementos de terras raras como instrumento de Smart Power da China. Estudos Internacionais, vol 3, 2015.

LEVKOWITZ, L., Beauchamp-MUSTAFAGA, N. China's rare earths industry and its role in the international market. U.S.-China Economic and Security Review Commission Staff Backgrounder, 2010

LIMA, P.C. Terras Raras: a importância de um plano estratégico. Estudos \& Pesquisas. Caderno As Legis, 2011

LYNAS CORPORATION. The path from here: Annual Report (2013). Disponível em: https:// www.lynascorp.com/wp-content/uploads/2019/05/130901-Annual-Report-2013.pdf. Acesso em: out. 2017

MACHADO, C.; LOURENÇO, N. Mudança global e geopolítica dos recursos naturais, 2012. Disponível em: http://www.igbpes.org/files/Carlos_MachadoMudanca_Global_e_Geopolitica_dos_Recursos_Naturais.pdf. Acesso em 25 abr. 2018.

MANCHERI, N. Does the WTO ruling against China on rare earths really matter? East Asia Forum: Economics, Politics and Public Policy in East Asia and the Pacific. Tokyo University, 2014.

MANCHERI, Nabeel. World trade in rare earths Chinese export restrictions and implications. Disponível em: https://www.researchgate.net/publication/283464807. Acesso em: 20 mar. 2018

MASSARI, S; RUBERTI, M. Rare earth elements as critical raw materials: Focus on international markets. Resources Policy, Lecce, n. 38, 2012.

MEDEIROS, C.A.; TREBAT, N.M. Transformando Recursos Naturais em Vantagem Industrial: o Caso da Indústria de Terras Raras na China. Brazil. J. Polit. Econ, vol.37, nº3, 2017.

MELO, F. R. A geopolítica das Terras Raras. Rev. Carta Internacional, Belo Horizonte, v. 12, n. 2, 2017.

MELO, Filipe Reis; DIAS, Hamana Karlla Gomes. A disputa por recursos estratégicos militares chega à OMC. Boletim Meridiano 47, v.16, n.151, 2015, p. 37-45

MORENO, C. O Brasil made in china: para repensar as reconfigurações do capitalismo contemporâneo. SP: Fundação Rosa Luxemburgo, 2015. 
MORRISON, W.M.; TANG, R. China's Rare Earth Industry and Export Regime: Economic and Trade Implications for the United States. US: Congressional Research Service, 2012.

NAMIBIA RARE EARTHS INC. How Are Rare Earths Used? Disponível em: < http://www. namibiarareearths.com/rare-earths-industry.asp>. Acesso em: 29 jul. 2017.

NAMIBIA RARE EARTHS INC. What are Rare Earths? Disponível em: $<$ http://www.namibiarareearths.com/rare-earths.asp> . Acesso em: 29 nov. 2017.

NYE, Joseph. O futuro do Poder. Trad. Magda Lopes. São Paulo: Benvirá, 2012.

OBSERVATORY OF ECONOMIC COMPLEXITY: [2016]. Disponível em: https://atlas.media. mit.edu/en/. Acesso em: 29 jun. 2019.

OLIVEIRA, H. Brasil e China: uma nova aliança não escrita? Rev. bras. polít. Int, 2010.

ORGANIZAÇÃO MUNDIAL DO COMÉRCIO. Measures Related to the Exportation of Rare Earths, Tungsten and Molybdenum (China - Rare Earths): WT/DS431, WT/DS432 e WT/ DS433. Disponível em: https://www.wto.org/english/tratop_e/dispu_e/cases_e/ds431_e.htm. Acesso em: 07 jul. 2020.

PETERS, S. Coercive western energy security strategies: 'resource wars' as a new threat to global security. Geopolitics, vol. 9, no 1, 2004

RAMOS, Leonardo; GARCIA, Ana; PAUTASSO, Diego; RODRIGUES, Fernanda. A decade of emergence: the BRICS institutional densification process. Journal of China and International Relations, v. 6, n. 1, p1-15. Pequim: JCIR, 2018

REIS, F. M. A geopolítica das terras raras. Carta Internacional, v. 12, n. 2, p. 219 - 243, 2017.

REPORTLINKER. Rare Earth Market Reports 2016. Disponível em: https://www.reportlinker.com/d0120679652/Global-Rare-Earth-Industry.html?pos=1. Acesso em: 1 jan. 2018.

RESEARCH IN CHINA. China Rare Earth Permanent Magnet Industry Report, 2009-2010". Disponível em: https://pt.scribd.com/document/39656865/China-Rare-Earth-Permanent-Magnet-Industry-Report-2009-2010-Research-in-China. Acesso em: 20 abr. 2018.

ROBINSON, Michael A. Rare earths provide critical weapons support. [S.l.]: Defense Media Network. Apr. 2011. Disponível em: < http://www.defensemedianetwork.com/stories/rareearthsprovide-critical-weapons-support/>. Acesso em: 10 mar. 2020.

ROCIO, M; SILVA, M; CARVALHO, P; CARDOSO, J. Terras-raras: situação atual e perspectivas. BNDES Setorial, no 35, 2013. Disponível em: http://www.bndes.gov.br/SiteBNDES/bndes/ bndes_pt/Institucional/Publicacoes/Consulta_Expressa/Tipo/BNDES_Setorial/201203_11. html. Acesso em: 20 abr. 2018.

SANTOS, C.J. A disputa sino-estadunidense na OMC e a importância das terras raras na indústria de defesa. Dissertação (Mestrado) - Programa de Pós-Graduação em Ciência Política, Universidade Federal de Pernambuco, Recife, 2014.

SCHMID, M. Mitigating supply risks through involvement in rare earth projects: Japan's strategies and what the US can learn. Resources Policy, 63, art. no. 101457, 2019.

SERRA, O. Terras raras: Brasil x China. Journal of the Brazilian Chemical Society, São Paulo, 2011.

STRANGE, Susan. States and Markets. London: Pinter Publishers, 1994.

TSE, Pui-Kwan. China's rare-earth industry. U.S. Geological Survey Open-File Report, 2011.

UNITED STATE GEOLOGICAL SURVEY. Mineral commodity summaries rare earths. Reston: USGS, 2019.

WALL, David. 'China as a trade partner: threat or opportunity for the OECD?' International Affairs, v. 72, n. 2, 1996.

WUBBEKE, J. Rare earths in China: policies and narratives of reinventing an industry. Resources Policy, 2013.

YERGIN, Daniel. A busca: Energia, segurança e a reconstrução do mundo moderno. Rio de Janeiro: Intrínseca, 2014. 